\title{
Assessment of the Morphometric Variation of Fruits and Phylogenetics of Elaeocarpus ganitrus (Woodenbegar) and Elaeocarpus serratus (Ceylon Olive)
}

\author{
W.G.A.S. Sumanarathne ${ }^{1}$, L.T. Ranaweera ${ }^{1}$, C.K. Weebadde ${ }^{2}$ and S.D.S.S. Sooriyapathirana ${ }^{*}$ \\ Date Received: $28^{\text {th }}$ August 2019 / Date Accepted: $21^{\text {st }}$ February 2020
}

\begin{abstract}
Purpose: Elaeocarpus ganitrus and E. serratus are two significant tropical fruit tree species. E. ganitrus is also important for its endocarps that are popularly known as Rudraksha. However, these are underutilized species in Sri Lanka. Therefore, present study was conducted to assess the morphometric diversity of fruits and endocarps and the phylogenetic relationships of two species using DNA barcoding markers.

Research Method: The ripe fruits were collected from a set of trees of two species in Matale and Kandy districts. The fruit and endocarp size parameters were measured in two seasons and subjected to statistical analysis. The trnH-psbA and trnL-trnF sequences were obtained from the selected trees and subjected to phylogenetic analysis.

Findings : The fruit size traits were predominantly affected by the intraspecific variation than the environment. The length and diameter of the endocarps were seasonal independent and tree specific. Except colour, people preferred E. serratus fruits than E. ganitrus fruits. The markers, trnH-psbA and trnL-trnF unravelled the species delimits of E. ganitrus and E. serratus. The trnL-trnF based phylogeny positioned the trees of E. ganitrus in the respective clade. E. serratus trees were cladded with E. stipularis, E. tectorius, E. dongnaiensis and E. glaber.
\end{abstract}

Research Limitations: A limited sequence pop-set for Elaeocarpus spp. is available in literature for comparison. The meta-scale attempts are needed to resolve the phylogenetic relationships of Elaeocarpus germplasm.

Originality / Value : The revealed morphological and phylogenetic relationships of E. ganitrus and E. serratus lay the platform for germplasm conservation and crop improvement programs in Sri Lanka.

Keywords: Blue Weralu, Elaeocarpaceae, Indian bead tree, Indian olive, Nil Weralu, Rudraksha, Weralu

\section{INTRODUCTION}

The members of the genus Elaeocarpus L. of the family Elaeocarpaceae are well-known for their delicious fruits in South Asia (Pant et al., 2013). Typically, Elaeocarpus serratus L., (English: Ceylon Olive / Indian olive; Sinhala: Weralu; Tamil: Veralikkai) and E. ganitrus Roxb. Ex G. Don [Alias E. spharicus] (English: Woodenbegar / Indian Bead Tree; Rudraksha-Fruit; Sinhala: Nil Weralu; Tamil: Ruttiratcam) are preferred over the other species in the genus because $E$. ganitrus and E. serratus bear colourful fruits with edible pulp (Coode, 2004; Das, 1987; Rahman et al., 2003). The higher preference for the fruits of Elaeocarpus spp. is attributed to the unique

taste and the rich medicinal values (Coode, 2004). Though Elaeocarpus is the most popular genus, the family Elaeocarpaceae contains a total of 12 genera and more than 550 known species (Christenhusz and Byng, 2016). Among them, more than 350 species belong to the genus Elaeocarpus L. and within this genus; majority

\footnotetext{
Department of Molecular Biology and Biotechnology, Faculty of Science, University of Peradeniya, 20400, Sri Lanka

sunethss09@gmail.com

2 Department of Plant, Soil and Microbial Sciences, College of Agriculture and Natural Resources, Michigan State University, East Lansing, Michigan, USA.
}

(D) ORCID http://orcid.org/0000-0002-5592-1742

\section{(c) (1) (8)(2)}


of the species possess edible mesocarps (Coode, 2004). However, despite having numerous and well-known regional floras, there is an ample amount of ambiguity over the number of taxa within the genus (Baba, 2013; Coode, 1983; Coode, 2010; Zmarzty, 2001).

The tropical and sub-tropical regions provide the ideal habitats to almost all the genera of the family Elaeocarpaceae, however, some chose to grow in temperate countries (Baba, 2013). Moreover, the family Elaeocarpaceae is known to have a southern origin. Members of this family are more abundant in South America, Southeast Asia, Madagascar and Australia. Furthermore, no evidence is found to confirm the existence of this family in Africa, thereby supporting the theory of southern origin (Raven and Axelrod, 1974). E. serratus has a wide range of distribution extending from southern India to Nepal and Java, and said to be indigenous to India and Sri Lanka (https://npgsweb.ars-grin.gov). Moreover, $E$. serratus trees are cultivated mainly in Australia, Brazil, China, Ghana and, other Asian countries (Pushpakumara et al., 2007). E. ganitrus species is mainly distributed in the South-east Asian countries such as India, Nepal, Myanmar (Singh et al., 2016) and central areas of Sri Lanka.

E. ganitrus is a large evergreen tree bearing bright-deep blue coloured fruits upon maturation (Singh et al., 2003; Kumar et al., 2008). However, the blue colour is limited to the epidermis of the exocarp, and the inner edible mesocarp is usually bright green (Lee, 1991). The endocarp is a hard-lignified stone (i.e., endocarp) with strong electromagnetic properties (Singh et al., 2016; Pant et al., 2013). Moreover, the leaves are broad and simple and, they turn in to red near to senescence (Pant et al., 2013). Particularly, E. ganitrus is not an ornamental tree; instead, it inhabits tropical evergreen forests (Singh et al., 2003). Surprisingly, the unripen fruits are not edible however, ripen fruits have a sweet-sour taste and usually being eaten raw or as pickles (Coode, 2004). Furthermore, the endocarp is a famous curative agent in Ayurvedic medicine due to their electromagnetic properties and the Hindu people use endocarps as Rudraksha (i.e., tear drops of load Shiva) beads to make necklaces or rosaries, to wear as religious accessories (Coode,
2004; Coode, 2010). In general, leaf, seed and fruit pulp extracts of E. ganitrus are known to have significant applications in treating the patients with blood and heart-related diseases, brain and nerve disorders and, abnormalities associated with respiratory and digestive tract (Kumar et al., 2008; Pant et al., 2013; Singh et al., 2003; Singh et al., 2016). In Sri Lanka, E. serratus is an abundantly growing tree in the lower altitude forests in wet and intermediate zones (Dassanayake, 1980; Pushpakumara et al., 2007). There is a tremendous amount of medicinally valuable constituents present in E. serratus (Mohanan and Sabu, 2002). The $E$. serratus fruits are consumed fresh at ripen stage and prepared as spiced and salted pickle in raw stage. Moreover, the leaf extracts of E. serratus contain anti-oxidative components.

However, E. ganitrus and E. serratus of Sri Lanka remain as under-utilized tree species. The morphological diversity of fruits and endocarps has not been assessed with respect to the individual tree variation and the environment to use in germplasm utilization and conservation. The phylogenetic relationships of species in family Elaeocarpaceae have been recently studied (Baba, 2013). However, E. ganitrus and E. serratus of Sri Lanka have not been studied for the species delimits and the phylogenetic relationships. Therefore, the present study was carried out to assess the fruit and endocarp morphological diversity and the phylogenetic relationships of E. ganitrus and E. serratus of Sri Lanka in relation to the sequences reported for the other species in Elaeocarpaceae.

\section{MATERIALS AND METHODS}

\section{Sample collection}

The fruits were collected from E. serratus (ES) and E. ganitrus (EG) trees within Matale and Kandy Districts, Sri Lanka. Total of 30 trees were selected, 15 trees from each species (Figure $01)$. A total of 15 fully ripe fruits and five seeds were randomly collected from each tree for the morphological analysis. The fruit and seed morphological analyses were undertaken in 2018 and 2019 fruiting seasons (January-May). 
The rainfall and temperature data of the fruit collecting districts are given in Figure 01.

\section{Morphological data collection}

The fruit and seed size parameters; weight, length and width, and colour in terms of Red-GreenBlue (RGB) were measured using a balance, Vernier calliper and by examining high-resolution photographs respectively. The leaf morphology was also qualitatively examined. All the morphological data collected were subjected to the normality testing followed by GLM procedure with main effects; species, season and tree ID, as well as their interactions. The significant mean differences were examined using LS-means and pdiff option in GLM procedure. All the statistical analytical procedures were performed using the Statistical Package SAS 9.4 (SAS Institute, NC, Cary, USA).

\section{Organoleptic assessment of ripe fruits}

The ripe fruits of E. serratus and E. ganitrus (bulked samples harvested from studied groups of trees) were given to a group of 30 taste-panellists to observe, taste and rank the fruit samples for the preferred levels of five organoleptic parameters; colour, aroma, texture, sourness and overall taste. The tasters were requested to use a three-tier scoring system (1: low; 2: moderate; 3: high). The rank data generated by the taste panel were subjected to association analysis (taste parameter vs. species) using FREQ procedure in SAS.

\section{DNA extraction}

The freshly collected immature leaf samples were used to extract genomic DNA. The DNA extractions were carried out based on the CTAB method (Doyle, 1990) which was optimized separately for E. ganitrus and E. serratus. For E. ganitrus, original CTAB method was used and extracted DNA was purified using phenol:chloroform:isoamyl alcohol and precipitated using ice-cold isopropanol. For $E$. serratus, the original CTAB method was modified by adding poly-vinyl-pyrrolidone (PVP) $(0.1$ $\mathrm{g}$ in solid form) and $\beta$-mercaptoethanol (4\% - $1.5 \mu \mathrm{l})$ to the initial grinding step. The DNA was purified using two consecutive purification steps of chloroform: isoamyl alcohol. The DNA precipitation was done using ice-cold isopropanol and $5 \mathrm{M} \mathrm{NaCl}$. The DNA pellets were washed with $70 \%$ ethanol and ammonium acetate, dissolved in TE buffer and stored at $-20^{\circ} \mathrm{C}$.
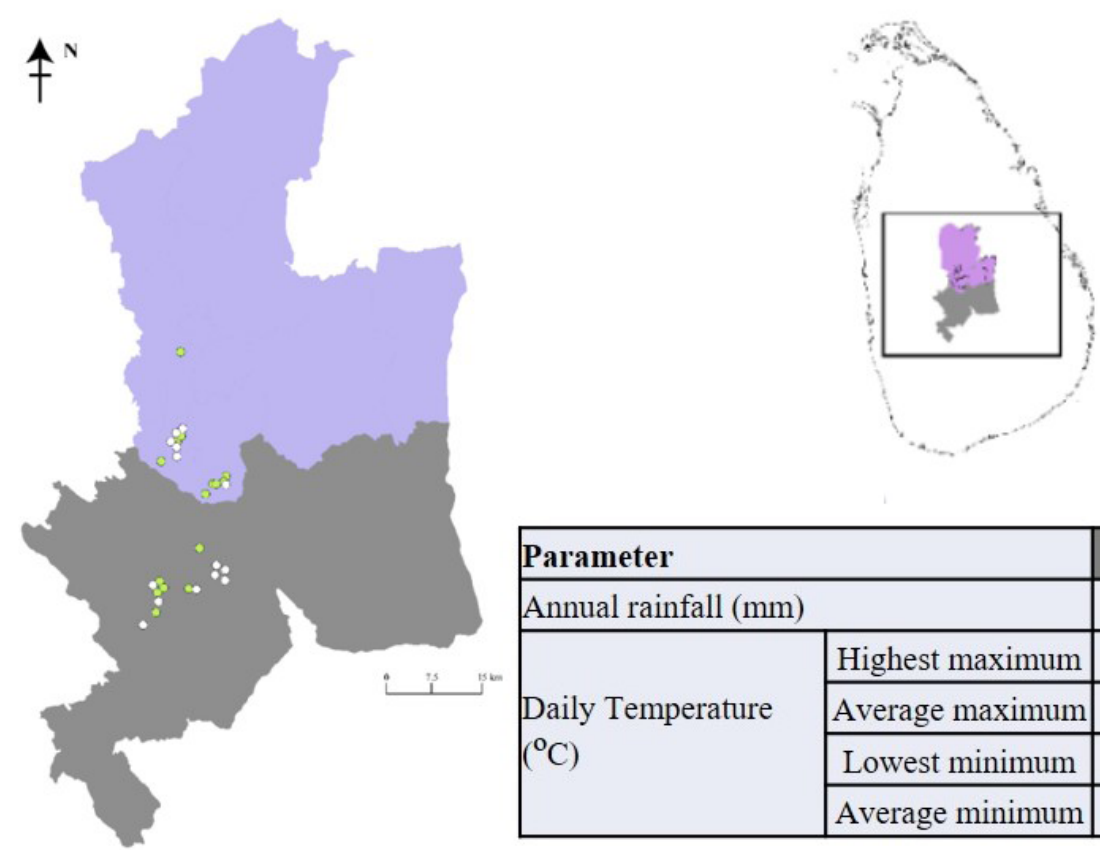

\begin{tabular}{|c|c|c|c|}
\hline \multicolumn{2}{|l|}{ Parameter } & Kandy & Matale \\
\hline \multicolumn{2}{|c|}{ Annual rainfall (mm) } & 2368.8 & 3070.4 \\
\hline \multirow{4}{*}{$\begin{array}{l}\text { Daily Temperature } \\
\left({ }^{\circ} \mathrm{C}\right)\end{array}$} & Highest maximum & 38 & 35 \\
\hline & Average maximum & 29.4 & 31.1 \\
\hline & Lowest minimum & 13.6 & 13.2 \\
\hline & Average minimum & 29.4 & 20.1 \\
\hline
\end{tabular}

Figure 01: A map showing sampling locations. Purple and grey regions represent Matale and Kandy Districts of Sri Lanka respectively. Green dots: E. ganitrus (Woodenbegar). White dots: E. serratus (Ceylon olive) The annual rainfall and temperature data for 2018 are given. 


\section{PCR and DNA sequencing}

The DNA samples were subjected to PCR using the standard DNA barcoding markers; trnH-psbA (Pf: 5' CGC GCA TGG TGG ATT CAC AAT CC 3'; Pr: 5' GTT ATG CAT GAA CGT AAT GCT C 3') (Sang et al., 1997) and trnL-trnF (tRNA-leu gene) (Pf: 5' CGA AAT CGG TAG ACG CTA CG 3'; Pr: 5' GGG GAT AGA GGG ACTTGA AC 3') Taberlet et al., 2007). The PCR solution mixtures $(15 \mu 1)$ were prepared with $1 \times$ Go Taq ${ }^{\circledR}$ Green Master Mix (7.5 $\mu$ l) (Promega Corporation, Madison, Wisconsin, USA), forward and reverse primers $(10 \mathrm{ng} / \mu \mathrm{l}-0.5 \mu \mathrm{l}$ each), nuclease free water $(5.5 \mu \mathrm{l})$, spermidine $\left(1.34 \times 10^{-4} \mathrm{~mol} / \mathrm{dm}^{3}\right.$ - $3.5 \mu 1)$, bovine serum albumin (BSA) $(4 \%$ $0.2 \mu \mathrm{l})$ and DNA template $(1.0 \mu \mathrm{l}-60 \mathrm{ng} / \mu \mathrm{l})$. All PCR work was carried out using a Takara thermal cycler (Otsu Shiga, Japan). The PCR cycles consisted of initial denaturation at $98^{\circ} \mathrm{C}$ for $45 \mathrm{sec}$ for $\operatorname{trnH}-p s b A$, and $95^{\circ} \mathrm{C}$ for $5 \mathrm{~min}$ for trnL-trnlF, then 35 cycles of denaturation at 98 ${ }^{\circ} \mathrm{C}$ for $10 \mathrm{sec}$ for trnH-psbA and $95^{\circ} \mathrm{C}$ for $30 \mathrm{sec}$ for $t r n L-t r n F, 30 \mathrm{sec}$ of primer annealing at $64{ }^{\circ} \mathrm{C}$ for trnH-psbA and $50{ }^{\circ} \mathrm{C}$ for trnL-trnF, extension at $72{ }^{\circ} \mathrm{C}$ for $40 \mathrm{sec}$ for trnh-psbA, and $2 \mathrm{~min}$ for trnL-trnF. The final extension was done at 72 ${ }^{\circ} \mathrm{C}$ for $10 \mathrm{~min}$ for trnH-psbA and 4 min for trnLtrnF (Sang et al., 1997; Taberlet et al., 2007). The PCR products were visualized using 1\% agarose gel electrophoresis and purified using Wizard SV gel ${ }^{\circledR}$ PCR clean-up system (Promega Corporation, Madison, Wisconsin, USA). The purified PCR products were subjected to DNA sequencing using an ABI 3500 Genetic Analyzer (Applied Biosystems, Cat. No. 4405186).

\section{Phylogenetic analysis}

Initially, the two sets of sequences obtained for markers trnH-psbA and trnL-trnF were visualized in MEGA v7 (Kumar et al., 2016). Then the initial and end buffers were trimmed, and the two sets of sequences were aligned separately using MEGA v7. To reconstruct the phylogeny of family Elaeocarpaceae, we adapted sequences reported in Baba, (2013) and other relatable reference sequences obtained from Basic Local Alignment Search Tool (BLAST) search of NCBI (Table 1). The alignment was carried out in MEGA v7 utilizing the Clustal W algorithm (Thompson et al., 1994). Then the alignment was checked manually for further clarifications to remove unwanted gaps. The INDELS and SNPs were identified from the alignment. The Maximum Likelihood (ML) tree search was carried out in RAxML (Stamatakis, 2006) applying the rapid bootstrap algorithm (Stamatakis et al., 2008). The DNA model was selected as GTRGAMMA and the analysis was carried out for 1000 iterations (Rodriguez et al., 1990). By applying the bipartition option in RAxML, the bootstrap replicates were concluded into a single tree topology. Then the Bayesian analysis was carried out in MrBays (Huelsenbeck and Ronquist, 2001). A model selection was carried out using Corrected Akaike Information Criteria (AICc) (Cavanaugh, 1997), Bayesian Information Criteria (BI) and Decision Theory (DT). The best-suited parameters (HIK model- $\mathrm{f}$ (a): 0.34, f(c): 0.18, f (g): 0.17, f(t): 0.31, kappa: 2.45) were employed in the Bayesian tree search and ran four Markov Chain Monte Carlo (MCMC) chains for 50 million cycles. The $50 \%$ majority rule consensus tree was drawn for all the trees probed after the burn-in. All the analyses were carried out in CIPRES science gateway (Miller et al., 2010). The phylogenetic trees were modified using FigTree v1.4.3 software (Rambaut, 2014) for better visualization.

The E. ganitrus trees are evergreen and grow up to $15-75 \mathrm{~m}$ in height. The trunk is prominent, and leaves and branches are nested as a crown in the top (Figure 2Ai). The E. serratus trees are also evergreen; however, medium sized (5-30 m) (Figure 2Bi) compared to E. ganitrus trees. In $E$. serratus, the tree branching could happen after 2-4 m of growth under natural conditions (Figure 2B). The fruiting is occurred in all the branches however, it is prominent in distal branches formed recently (Figures 2Aii and 2Bii). 
Table 01: The Elaeocarpus DNA sequences subjected to phylogenetic analysis

\begin{tabular}{|c|c|c|c|c|c|c|}
\hline \multirow{2}{*}{ Species } & \multirow{2}{*}{ Common name } & \multirow{2}{*}{ Voucher No. } & \multirow{2}{*}{ Geographic area } & \multicolumn{2}{|c|}{ GenBank accession } & \multirow{2}{*}{ Reference } \\
\hline & & & & $\operatorname{trn} L-t r n F$ & $\operatorname{trnH} H-p s b A$ & \\
\hline E. ganitrus & Woodenbegar & DMB123 & Sri Lanka & MN128522 & MN119517 & \multirow{5}{*}{ This study } \\
\hline E. ganitrus & & DMB124 & Sri Lanka & MN128523 & MN119518 & \\
\hline E. ganitrus & & DMB125 & Sri Lanka & MN128524 & MN119519 & \\
\hline E. ganitrus & & DMB126 & Sri Lanka & MN128525 & MN119520 & \\
\hline E. ganitrus & & DMB127 & Sri Lanka & MN128526 & MN119521 & \\
\hline E. serratus & \multirow[t]{5}{*}{ Ceylon olive } & DMB128 & Sri Lanka & MN128527 & MN119522 & \multirow{5}{*}{ This study } \\
\hline E. serratus & & DMB129 & Sri Lanka & MN128528 & MN119523 & \\
\hline E. serratus & & DMB130 & Sri Lanka & MN128529 & MN119524 & \\
\hline E. serratus & & DMB131 & Sri Lanka & MN128530 & MN119525 & \\
\hline E. serratus & & DMB132 & Sri Lanka & MN128531 & MN119526 & \\
\hline E. grandis & & - & Australia & KC428500.1 & - & \multirow{10}{*}{ NCBI } \\
\hline E. stipularis & & - & Not available & AB920774.1 & - & \\
\hline E. tectorius & & - & Not available & AB920775.1 & - & \\
\hline E. apiculatus & & - & Not available & JN676060.1 & - & \\
\hline E. largiflorens & & 71 & Australia & KC428501.1 & - & \\
\hline E. angustifolius & & 184418 & Australia & DQ444689.1 & - & \\
\hline E. hainanensis & & - & Not available & JN676061.1 & - & \\
\hline E. dentatus & & 630341 & New Zealand & KF591277.1 & - & \\
\hline E. hookerianus & & 630369 & New Zealand & KF591223.1 & - & \\
\hline E. blascoi & & - & India & HМ066938.1 & - & \\
\hline E. geminiflorus & & 710751 & Malaysia & KJ675695.1 & - & \multirow{41}{*}{ Baba, 2013} \\
\hline E. ptilanthus & & 554 & Papua New Guinea & KJ675716.1 & - & \\
\hline E. sphaericus & & 710753 & India & KJ631299.1 & - & \\
\hline E. grandis & & 27569 & Australia & KJ675700.1 & - & \\
\hline E. angustifolius & & 710750 & India & KJ631298.1 & - & \\
\hline E. hylobroma & & 838 & Australia & KJ675705.1 & - & \\
\hline E. rotundifolius & & 761 & New Caledonia & KJ675718.1 & - & \\
\hline E. seringii & & 2852 & New Caledonia & KJ675721.1 & - & \\
\hline E. speciosus & & 115 & New Caledonia & KJ675725.1 & - & \\
\hline E. alaternoides & & 749 & New Caledonia & KJ631296.1 & - & \\
\hline E. hortensis & & 2968 & New Caledonia & KJ675704.1 & - & \\
\hline E. brachypodus & & 71 & New Caledonia & KJ631303.1 & - & \\
\hline E. coumbouiensis & & 388 & New Caledonia & KJ631307.1 & - & \\
\hline E. gordonii & & 300 & New Caledonia & KJ675697.1 & - & \\
\hline E. gummatus & & 260 & New Caledonia & KJ675701.1 & - & \\
\hline E. bullatus & & 2906 & New Caledonia & KJ631304.1 & - & \\
\hline E. glaber & & 179 & Java, Indonesia & KJ675696.1 & - & \\
\hline E. dongnaiensis & & 1118 & Vietnam & KJ675690.1 & - & \\
\hline E. stipularis & & 10749 & Java, Indonesia & KJ675727.1 & - & \\
\hline E. largiflorens & & 503 & Australia & DQ444684.1 & - & \\
\hline Elaeocarpus sp. & & 397 & Australia & KJ675724.1 & - & \\
\hline E. elliffii & & 884 & Australia & KJ675691.1 & - & \\
\hline E. thelmae & & 792 & Australia & KJ675729.1 & - & \\
\hline E. grandiflorus & & 10751 & Malaysia & KJ675699.1 & - & \\
\hline E. dentatus & & NA & New Zealand & KJ675689.1 & - & \\
\hline E. ruminatus & & 446 & Australia & KJ675719.1 & - & \\
\hline E. sedentarius & & 408 & Australia & KJ675720.1 & - & \\
\hline E. holopetalus & & 605470 & Australia & KJ675702.1 & - & \\
\hline Elaeocarpus sp. & & 2 & Australia & DQ444676.1 & - & \\
\hline E. hookerianus & & 605721 & New Zealand & DQ444686.1 & - & \\
\hline E. hookerianus & & 787 & New Zealand & KJ675703.1 & - & \\
\hline E. stellaris & & 3531 & Australia & KJ675726.1 & - & \\
\hline Elaeocarpus sp. & & 4312 & Australia & KJ675723.1 & - & \\
\hline E. williamsianus & & 513 & Australia & DQ444693.1 & - & \\
\hline E. bancroftii & & 502 & Australia & DQ444685.1 & - & \\
\hline E. nouhuysii & & 533 & Papua New Guinea & KJ675713.1 & - & \\
\hline E. reticulatus & & 605722 & Australia & DQ444683.1 & - & \\
\hline E. eumundii & & 505 & Australia & DQ444682.1 & - & \\
\hline E. eumundii & & 4459 & Australia & KJ675692.1 & - & \\
\hline E. nouhuysii & & 530 & Papua New Guinea & KJ675712.1 & - & \\
\hline E. ferruginiflorus & & 882 & Australia & KJ675693.1 & - & \\
\hline
\end{tabular}




\begin{tabular}{|c|c|c|c|c|c|c|}
\hline \multirow{2}{*}{ Species } & \multirow{2}{*}{ Common name } & \multirow{2}{*}{ Voucher No. } & \multirow{2}{*}{ Geographic area } & \multicolumn{2}{|c|}{ GenBank accession } & \multirow{2}{*}{ Reference } \\
\hline & & & & trnL-trnF & trnH-psbA & \\
\hline E. michaelii & & 310 & Australia & KJ631310.1 & - & \\
\hline E. johnsonii & & 2122 & Australia & KJ675706.1 & - & \\
\hline E. coorangooloo & & 695 & Australia & KJ631308.1 & - & \\
\hline E. arnhemicus & & 341 & Australia & KJ631300.1 & - & \\
\hline E. bifidus & & 649 & Hawaii & KJ631302.1 & - & Baba, 2013 \\
\hline E. kerstingianus & & 21433 & Micronesia & KJ675707.1 & - & \\
\hline E. crenulatus & & 539 & Papua New Guinea & KJ631309.1 & - & \\
\hline E. carolinae & & 4444 & Australia & KJ631305.1 & - & \\
\hline E. foveolatus & & 856 & Australia & KJ675694.1 & - & \\
\hline
\end{tabular}

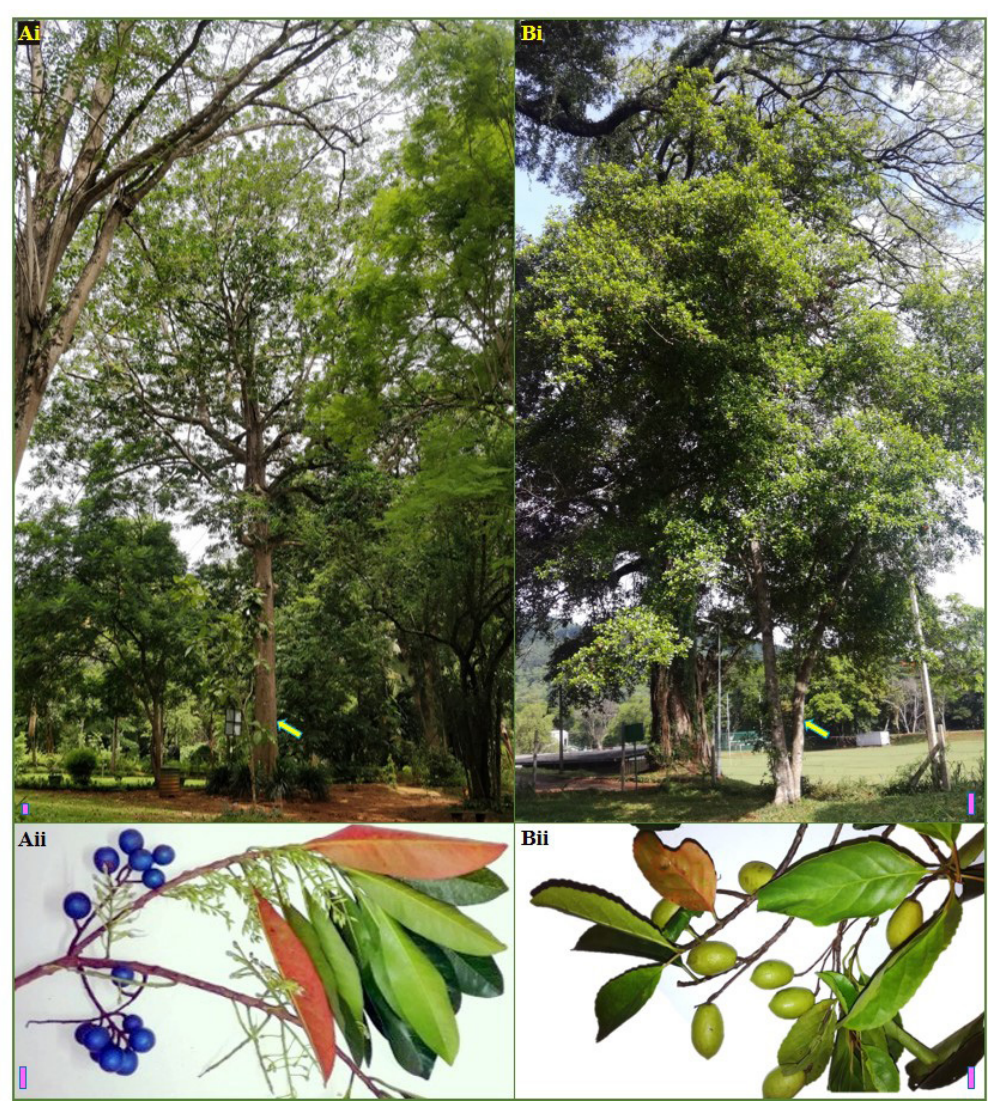

Figure 02: $\quad$ The fruit bearing trees and branches. A: E. ganitrus (Woodenbegar); B: E. serratus (Ceylon olive). i: trees; ii: branches. The scale bars represent $1 \mathrm{~m}$ and $1 \mathrm{~cm}$ in tree and branch figures respectively.

\section{Morphological variation of fruits}

E. ganitrus and E. serratus possess moderately glossy olive like fruits. E. ganitrus bears globular shaped fruits with bright ocean blue outer appearance. The blue coloration of the fruit skin of E. ganitrus can be slightly variable and the mean RGB values were found to be 15 , 62 and 108. The E. serratus fruits are ovoid in shape and possess yellowish green skin and the mean RGB values reported were 135, 131 and 30 (Table 2). The reported colours represent the fruits at maturity (i.e. harvestable stage) and in younger stages fruits are relatively dark green in colour. The E. ganitrus fruits develop blue colour in the later stage (last three to four weeks) of fruit development.
The analysis of variance of the fruit size traits revealed that, the effect of seasonal variation was significant $(\mathrm{p}<0.05)$. Within E. ganitrus and $E$. serratus, the fruit weight was determined by the seasonal effect and the individual tree; however, the effect of later was seven times higher (F values 10.9 vs 70.1 ) on deciding the fruit weight. The variation of the fruit length also affected significantly by the same trend of effects as in fruit weight; however, the interaction- effects were much more profound than those on fruit weight. The fruit diameter was not affected significantly by the seasonal variation and appeared to be a tree specific trait $(\mathrm{F}=43.8 ; \mathrm{p}<0.05)$. The mean values of fruit weight, length and diameter 
were significantly different among two species $(p<0.05)$. The summary of the analysis of variation of fruit morphological variation is shown in Table 03. Table 04 displays the mean values of fruit size parameters for two seasons. It was apparent that E. serratus fruits were heavier, longer and broader than the E. ganitrus fruits (p $<0.05$; Table 04).

The variation of the fruit weight, length and diameter are depicted in Figures 3A-3F. The seasonal effect was apparently much less than the effect of individual trees. The depicted variation of fruit size in Figure 3 is showcased with representative fruits taken from each tree in Figures 5Ai and 5Bi for E. ganitrus and $E$. serratus respectively. The longitudinal and cross sections of the fruits are shown in Figures 6Ai and 6Aii (E. ganitrus) and Figures 6Bi and 6Bii (E. serratus). The fruit size parameters were significantly and positively correlated with each other in which weight and length displayed the highest correlation $(\mathrm{PCC}=0.71 ; \mathrm{p}<0.05)($ Table 05).

Table 02: Qualitative morphological parameters of fruits, seeds and leaves of EG and ES

\begin{tabular}{|c|c|c|c|}
\hline Structure & Parameter & E. ganitrus & E. serratus \\
\hline \multirow{4}{*}{ Fruit } & Glossiness & Moderate & Moderate \\
\hline & Color & Bright ocean blue & Yellowish green \\
\hline & Mean RGB values of color & $15,62,108$ & $135,131,30$ \\
\hline & Shape & Globular & Ovoid \\
\hline \multirow{4}{*}{ Endocarp } & Color & Brown to dark brown & Brown to dark brown \\
\hline & Mean RGB values of color & $127,86,71$ & $134,90,71$ \\
\hline & Shape & Spherical & Ovoid \\
\hline & Surface texture & Rough & Rough \\
\hline \multirow{10}{*}{ Leaf } & \multirow{2}{*}{ Color } & Dark green (adaxial) & Green (adaxial) \\
\hline & & Green (abaxial) & Light and green (abaxial) \\
\hline & \multirow[t]{2}{*}{ Mean RGB values of color } & $30,45,22$ (adaxial) & 65, 92, 61 (adaxial) \\
\hline & & $83,105,45$ (abaxial) & 137, 157, 98 (abaxial) \\
\hline & Shape & Oblong & Oval-obovate \\
\hline & Margin & Serrulate & Shallowly serrate \\
\hline & Surface texture & Glabrous & Glabrous \\
\hline & Shape of the apex & Acute & Rounded-obtuse \\
\hline & Shape of the base & Acute & Acute \\
\hline & Venation pattern & Pinnate & Inter-marginal \\
\hline
\end{tabular}

Table 03: $\quad$ F-values and their significance - analysis of variance for fruit and seed morphometric data

\begin{tabular}{|c|c|c|c|c|c|c|c|c|}
\hline Parameter & $\mathrm{R}^{2}$ & Season (S) & Species (sp) & Tree ID (T) & $\mathrm{S} \times \mathrm{sp}$ & $\mathrm{S} \times \mathrm{T}$ & $\mathrm{sp} \times \mathrm{T}$ & $\mathrm{S} \times \mathrm{sp} \times \mathrm{T}$ \\
\hline \multicolumn{9}{|l|}{ Fruit } \\
\hline Weight (g) & $73.8 \%$ & $10.9 *$ & $836.9^{*}$ & $70.1 *$ & $0.5^{\mathrm{ns}}$ & $2.6^{*}$ & $34.9 *$ & $0.8^{\mathrm{ns}}$ \\
\hline Length (cm) & $86.6 \%$ & $10.0^{*}$ & $4449.4^{*}$ & $31.3^{*}$ & $17.3^{*}$ & $8.3^{*}$ & $18.6^{*}$ & $8.1^{*}$ \\
\hline Diameter $(\mathrm{cm})$ & $51.5 \%$ & $1.8^{\mathrm{ns}}$ & $82.5^{*}$ & $43.8^{*}$ & $4.0^{*}$ & $3.3^{*}$ & $8.1^{*}$ & $2.3^{\mathrm{ns}}$ \\
\hline \multicolumn{9}{|l|}{ Endocarp } \\
\hline Weight (g) & $52.8 \%$ & $8.8^{*}$ & $2.8^{\mathrm{ns}}$ & $9.5^{*}$ & $0.2^{\text {ns }}$ & $0.3^{\mathrm{ns}}$ & $8.1^{\mathrm{ns}}$ & $0.4^{\mathrm{ns}}$ \\
\hline Length (cm) & $91.8 \%$ & $3.8^{\mathrm{ns}}$ & $2098.2 *$ & $12.2^{*}$ & $2.5^{\mathrm{ns}}$ & $1.3^{\mathrm{ns}}$ & $26.2^{\mathrm{ns}}$ & $1.8^{\mathrm{ns}}$ \\
\hline Diameter $(\mathrm{cm})$ & $71.1 \%$ & $2.8^{\mathrm{ns}}$ & $125.5^{*}$ & $12.3^{*}$ & $0.6^{\mathrm{ns}}$ & $1.9^{\mathrm{ns}}$ & $18.0^{\mathrm{ns}}$ & $0.9^{\mathrm{ns}}$ \\
\hline
\end{tabular}

$* P \leq 0.05$; ns: nonsignificant $(P>0.05)$ 
Table 04: $\quad$ Variation of the size parameters of fruits and seeds

\begin{tabular}{cccccccc}
\hline \multirow{2}{*}{ Season } & \multirow{2}{*}{ Species } & \multicolumn{3}{c}{ Fruit } & \multicolumn{3}{c}{ Seed } \\
\cline { 3 - 8 } & & Weight $(\mathrm{g})$ & Length $(\mathrm{cm})$ & Diameter $(\mathrm{cm})$ & Weight $(\mathrm{g})$ & Length $(\mathrm{cm})$ & Diameter $(\mathrm{cm})$ \\
\hline \multirow{2}{*}{2018} & EG & $7.0^{\mathrm{b}}$ & $2.2^{\mathrm{b}}$ & $2.1^{\mathrm{b}}$ & $2.0^{\mathrm{a}}$ & $1.7^{\mathrm{b}}$ & $1.5^{\mathrm{a}}$ \\
& ES & $9.7^{\mathrm{a}}$ & $3.2^{\mathrm{a}}$ & $2.3^{\mathrm{a}}$ & $2.1^{\mathrm{a}}$ & $2.6^{\mathrm{a}}$ & $1.4^{\mathrm{b}}$ \\
\hline \multirow{2}{*}{2019} & EG & $7.4^{\mathrm{a}}$ & $2.2^{\mathrm{b}}$ & $2.1^{\mathrm{b}}$ & $2.1^{\mathrm{a}}$ & $1.7^{\mathrm{b}}$ & $1.6^{\mathrm{a}}$ \\
& ES & $9.9^{\mathrm{a}}$ & $3.1^{\mathrm{a}}$ & $2.2^{\mathrm{a}}$ & $2.2^{\mathrm{a}}$ & $2.7^{\mathrm{a}}$ & $1.4^{\mathrm{b}}$ \\
\hline
\end{tabular}

Means denoted by the same letters within columns are not significantly different at $P<0.05$. EG: E. ganitrus; ES: E. serratus

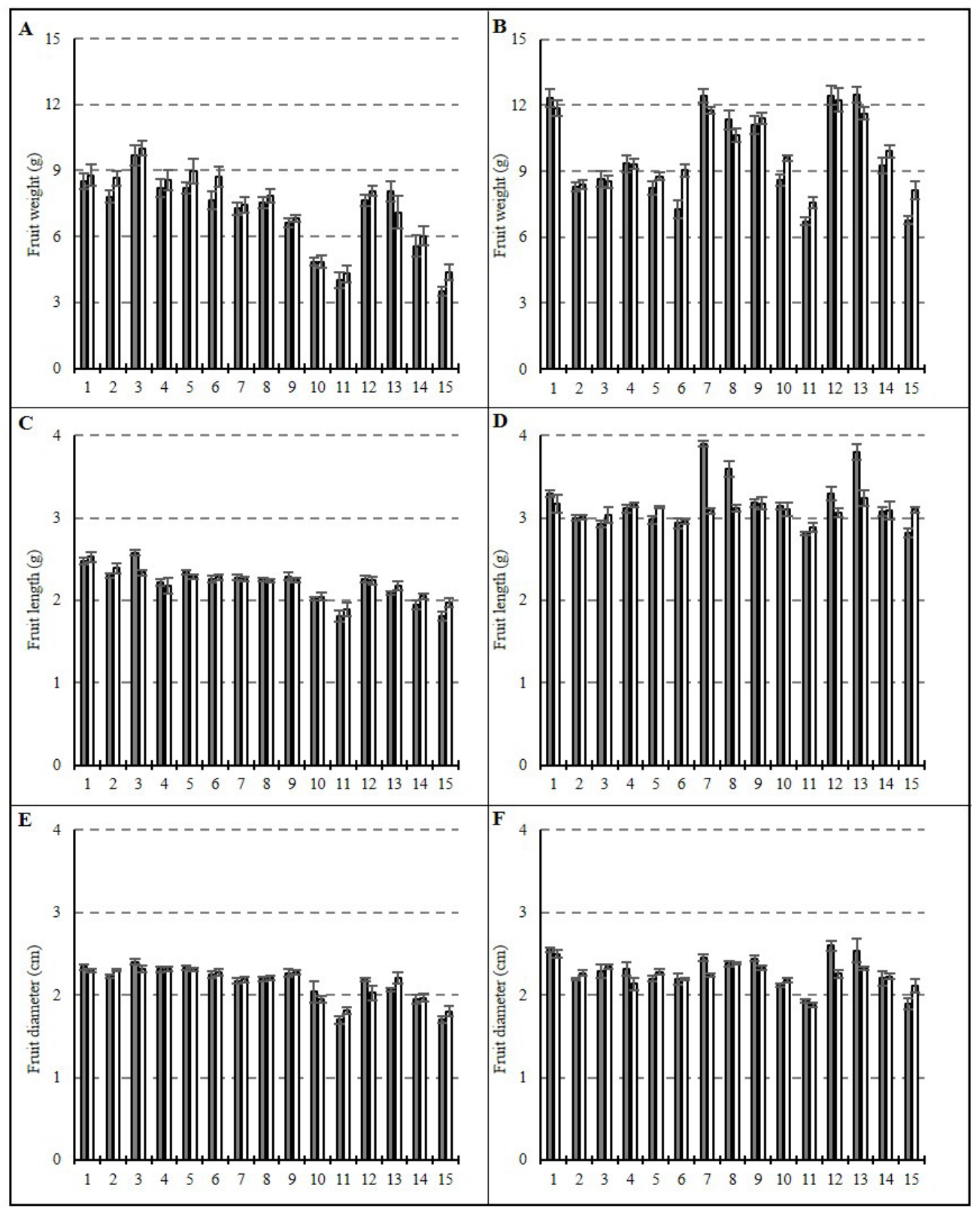

Figure 03: $\quad$ The variation fruit size parameters. A and B: Fruit weight (g); C and D: Fruit length (cm); E and F: Fruit Diameter. A, C and E: E. ganitrus (Woodenbegar); B, D and F: E. serratus (Ceylon olive). 1-15 are individual trees assessed for each species separately. The grey and white bars represent the mean variations in 2018 and 2019 fruiting seasons respectively. The error bars indicate the standard errors $( \pm)$. 


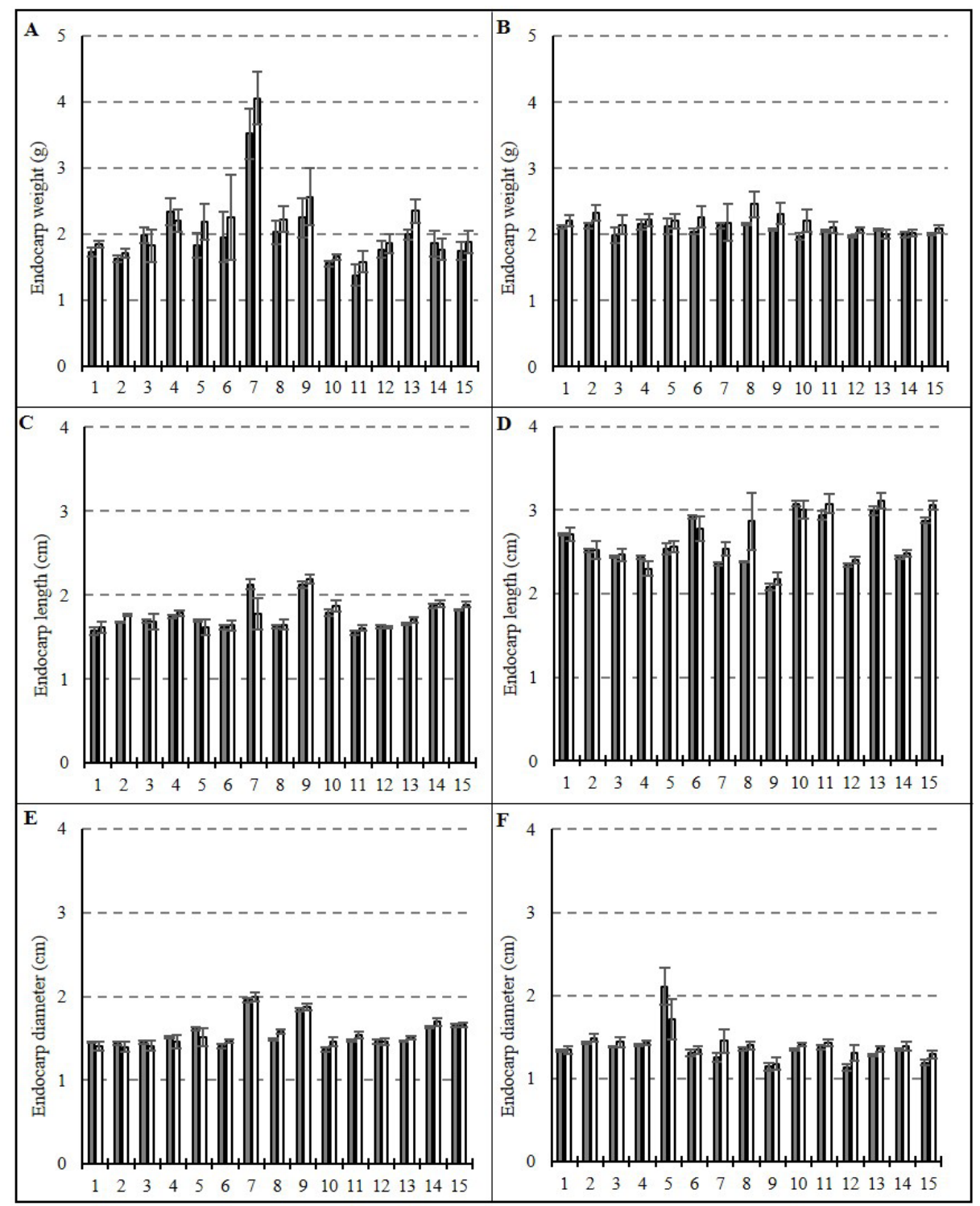

Figure 04: The variation seed size parameters. A and B: Seed weight (g); C and D: Seed length (cm); E and F: Seed diameter. A, C and E: E. ganitrus (Woodenbegar); B, D and F: E. serratus (Ceylon olive). 1-15 are individual trees assessed for each species separately. The grey and white bars represent the mean variations in 2018 and 2019 fruiting seasons respectively. The error bars indicate the standard errors $( \pm)$.

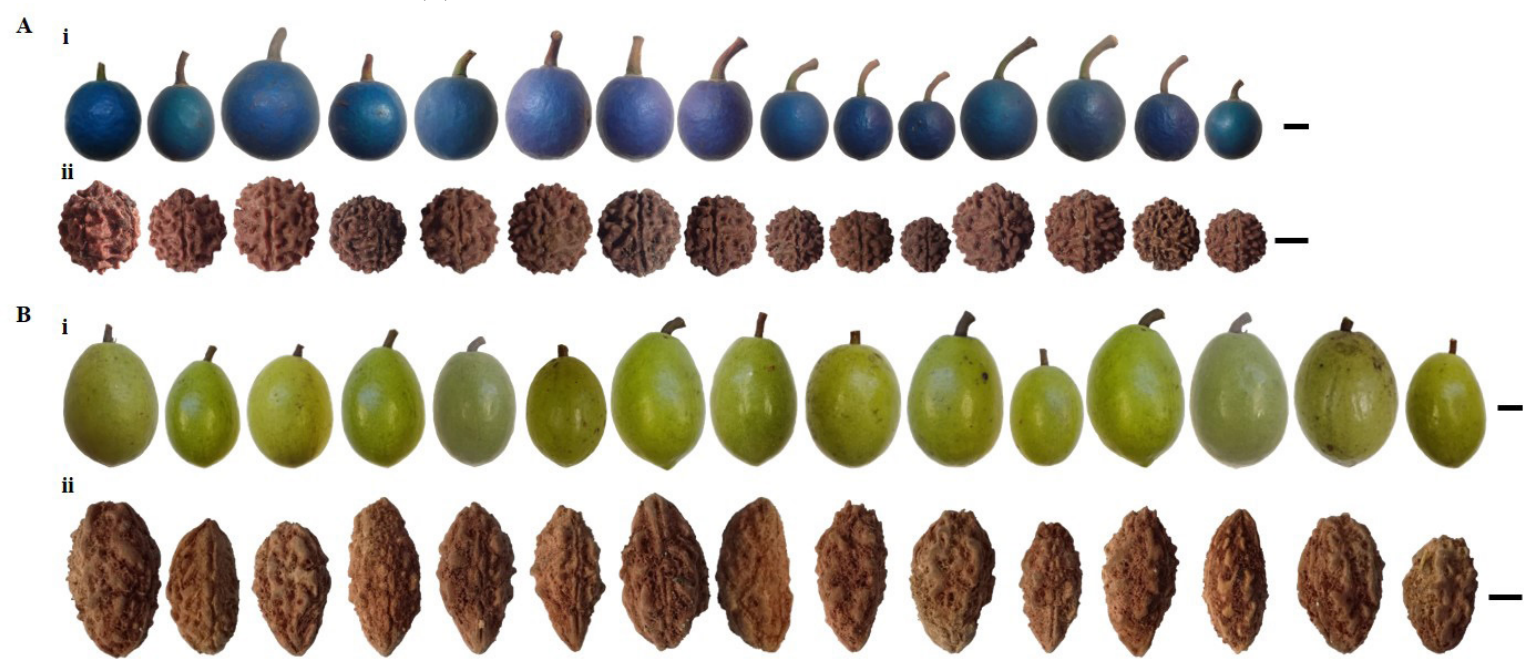

Figure 05: The variation of the fruits and seeds. A: E. ganitrus (Woodenbegar); B: E. serratus (Ceylon olive). i: Representative fruit from each of the 15 trees; ii: Representative seed from each of the 15 trees. Scale bars represent $1 \mathrm{~cm}$. 

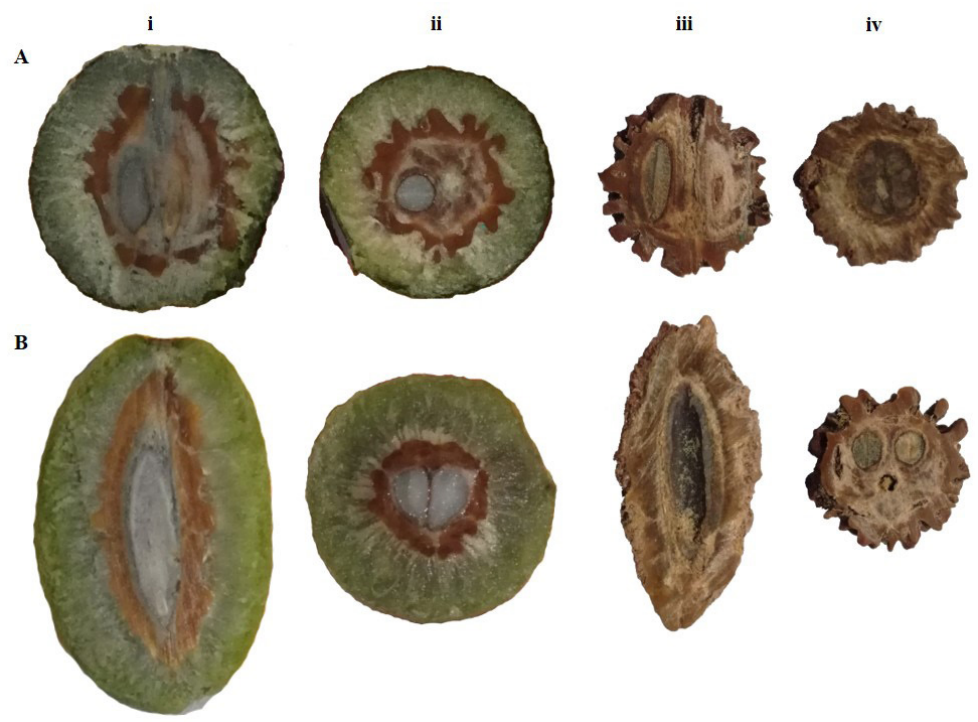

Figure 06: $\quad$ Sectional views of fruits and seeds. A: E. ganitrus (Woodenbegar); B: E. serratus (Ceylon olive). i and iii: Longitudinal sections; ii and iv: Cross sections. Scale bar represents $1 \mathrm{~cm}$.
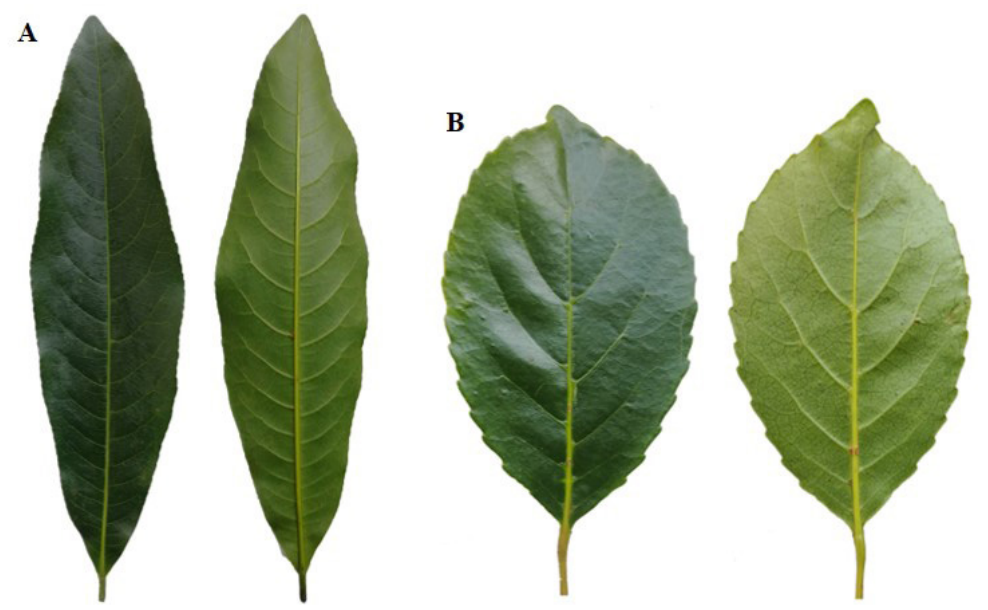

Figure 07: $\quad$ The appearance of leaves. A: E. ganitrus (Woodenbagar); B: E. serratus (Ceylon olive). Adaxial side (Left); Abaxial side (Right). Scale bar represents $1 \mathrm{~cm}$.

Table 05: Pearson Correlation coefficients among fruit size parameters

\begin{tabular}{lcc}
\hline & Weight $(\mathrm{g})$ & Length $(\mathrm{cm})$ \\
\hline Length $(\mathrm{cm})$ & $0.71^{*}$ & \\
Diameter $(\mathrm{cm})$ & $0.63^{*}$ & $0.45^{*}$ \\
\hline
\end{tabular}

$* P \leq 0.05 ;$ ns: nonsignificant $(P>0.05)$

\section{Morphological variation of endocarps}

The external colours of the endocarps of two species were not significantly varying and a variation of brown to dark brown coloration was observed. The mean RGB values were also not different in providing perceivable colour differences. The seeds are lighter in colour (creamish in early stages) and turn brown in maturity. The intense brownness was observed after processing endocarps for measurements or practically to make bead-necklaces. The colours reported in the present study represent the mature endocarps. The spherical and ovoid shapes could be observed for the endocarps of E. ganitrus and E. serratus respectively (Table 2 ).

The analysis of the variance of weight, length and diameter of endocarps revealed that the seasonal effect was only significant in determining the 
weight $(\mathrm{F}$-value $=8.8 ; \mathrm{p}<0.05)$. The length and diameter of endocarps were not significantly affected by season $(\mathrm{p}>0.05)$. The individual tree (i.e. Tree ID) variation for weight, length and diameter were significantly profound $(\mathrm{p}<0.05)$. The endocarp weights of two species were not significantly different whereas length and diameter reported significant differences between the two species. The summary of the analysis of variance for endocarp-size traits are given in Table 03. It is also important to note that the interaction terms of the main effects did not have a significantly different effect on the size of the endocarps. Table 04 summarizes the mean differences of endocarp weight, length and diameter. Although the weight of the endocarps of both the species are similar $(2.0-2.2 \mathrm{~g})$, the endocarps of $E$. ganitrus were significantly shorter and broader compared to that of E. serratus ( $p<0.05$; Table $4)$. The mean variations of the endocarps of the individual trees are depicted in Figures $4 \mathrm{~A}$ and 4B (weight), Figures 4C and 4D (length) and Figures $4 \mathrm{E}$ and $4 \mathrm{~F}$ (diameter). The variation of endocarp size given in Figure 4 is shown Figure 5Aii (E. ganitrus) and Figure 5Bii (E. serratus) by means of representative endocarp selected from each assessed tree. The longitudinal and cross sections of fruits and endocarps of E. ganitrus and E. serratus are displayed in Figures 6Aiii, 6Aiv, 6Biii and 6Biv respectively. The size traits of the endocarps were not strongly correlated where only diameter was separately correlated with weight and length $(\mathrm{p}<0.05)$. The endocarp length and diameter were negatively correlated showing an inverse relationship between the two traits $(\mathrm{PCC}=-0.24 ; \mathrm{p}<0.05)$ (Table 06).

The details of the morphological appearance of the leaves of E. ganitrus and E. serratus are indicated in Table 2. In general, the leaves of $E$. ganitrus are larger and darker. Two representative leaves at fully grown stage of the two species are given in Figure 7A (E. ganitrus) and 7B (E. serratus).

\section{Variation in organoleptic preference on fruits}

All the organoleptic parameters of the ripe fruits got significant associations with the species $(\mathrm{p}<0.05)$. The colour of the fruits of E. ganitrus fruits were highly preferred (as ranked by 70.0 $\%$ of respondents) than E. serratus fruits (33.3 $\%)$. However, the higher ratings were received by E. serratus fruits for all the other organoleptic parameters. The highest significant association was reported for aroma (Chi-square=26.9; $\mathrm{p}<0.05)$. The summary of the association analysis for organoleptic properties are given in Table 07.

Table 06: $\quad$ Pearson Correlation coefficients among seed size parameters

\begin{tabular}{lcc}
\hline & Weight $(\mathrm{g})$ & Length $(\mathrm{cm})$ \\
\hline Length $(\mathrm{cm})$ & $0.01^{\mathrm{ns}}$ & \\
Diameter $(\mathrm{cm})$ & $0.26^{*}$ & $-0.24^{*}$ \\
\hline
\end{tabular}

$* P \leq 0.05$; ns: nonsignificant $(P>0.05)$

Table 07: Association analysis of the organoleptic parameters of fruits

\begin{tabular}{|c|c|c|c|c|c|}
\hline \multirow{2}{*}{ Association } & \multirow{2}{*}{ Species } & \multicolumn{4}{|c|}{ Percentage respondents } \\
\hline & & Low (1) & Moderate (2) & High (3) & Chi-square value \\
\hline \multirow{2}{*}{ Color vs. species } & E. ganitrus & 6.7 & 23.3 & 70.0 & \multirow{2}{*}{$12.1 *$} \\
\hline & E. serratus & 0.0 & 66.7 & 33.3 & \\
\hline \multirow{2}{*}{ Aroma vs. species } & E. ganitrus & 76.7 & 20.0 & 3.3 & \multirow{2}{*}{$26.9^{*}$} \\
\hline & E. serratus & 16.7 & 23.3 & 60.0 & \\
\hline \multirow{2}{*}{ Texture $v s$. species } & E. ganitrus & 36.7 & 46.7 & 16.7 & \multirow{2}{*}{$14.1 *$} \\
\hline & E. serratus & 3.3 & 43.3 & 53.3 & \\
\hline \multirow{2}{*}{ Sourness vs. species } & E. ganitrus & 46.7 & 40.0 & 13.3 & \multirow{2}{*}{$11.5^{*}$} \\
\hline & E. serratus & 10.0 & 50.0 & 40.0 & \\
\hline \multirow{2}{*}{ Overall taste $v s$. species } & E. ganitrus & 46.7 & 33.3 & 20.0 & \multirow{2}{*}{13.3} \\
\hline & E. serratus & 10.3 & 27.6 & 62.1 & \\
\hline
\end{tabular}




\section{Phylogenetic analysis}

There are no nucleotide sequence differences of two loci within each species for the trees assessed. However, there is a considerable variation present between two species. In the trnH-psbA marker region, there are five SNPs and two INDELS present; a nine-base deletion in E. serratus (49-57 bp) and a six-base deletion in E. ganitrus (102-107 bp). In the trnL-trnF marker region, there are four SNPs two INDELs present; one-base deletion in E. serratus (773 bp) and a 17-base deletion in E. ganitrus (815$831 \mathrm{bp}$ ) (Figure 08). Almost similar topologies were obtained for both ML and Bayesian trees drawn for trnL-trnF marker region. However, the Bayesian tree was more resolved than the ML tree thus shown in the present study (Figure 09). According to the Bayesian tree, separate clusters are formed by E. ganitrus and E. serratus. A separate clade is formed by the assessed trees of E. serratus accessions and other five Elaeocarpus spp. (E. stipularis, E. tectorius, E. dongnaiensis, E. glaber) while the assessed trees of E. ganitrus are assembled with nine Elaeocarpus spp. (E. grandis, E. angustifolius, E. ptilanthus, E. sphaericus, E. hylobroma, E. geminiflorus, E. largiflorens subsp.) forming a separate clade (Figure 09).

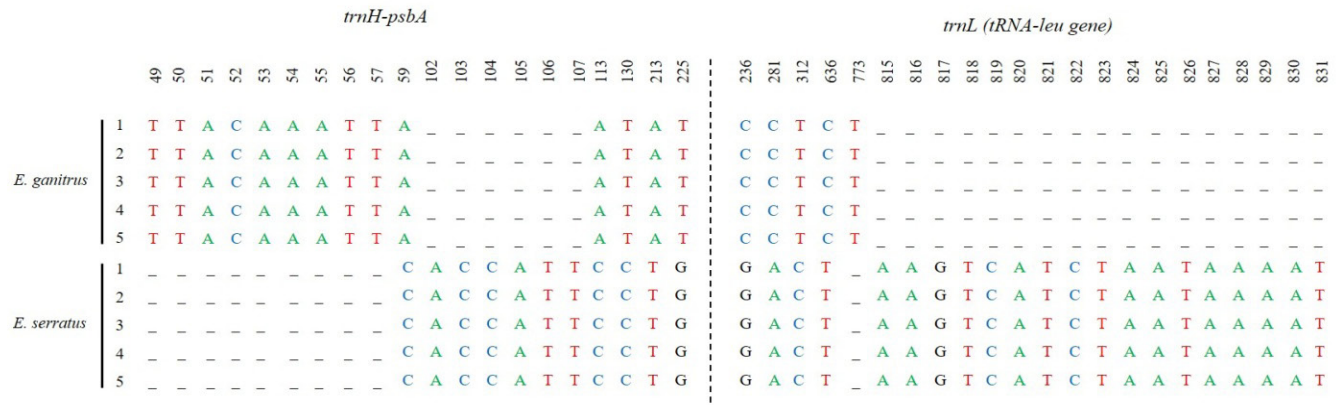

Figure 08: $\quad$ The SNP and INDEL profile $E$. ganitrus and $E$. serratus at the polymorphic sites of $t r n H-p s b A$ and trnL-trnF. Names of the markers and the positions of the SNPs and INDELS are given above the sequences. 1, 2, 3, 4 and 5 indicate five different trees for each species.

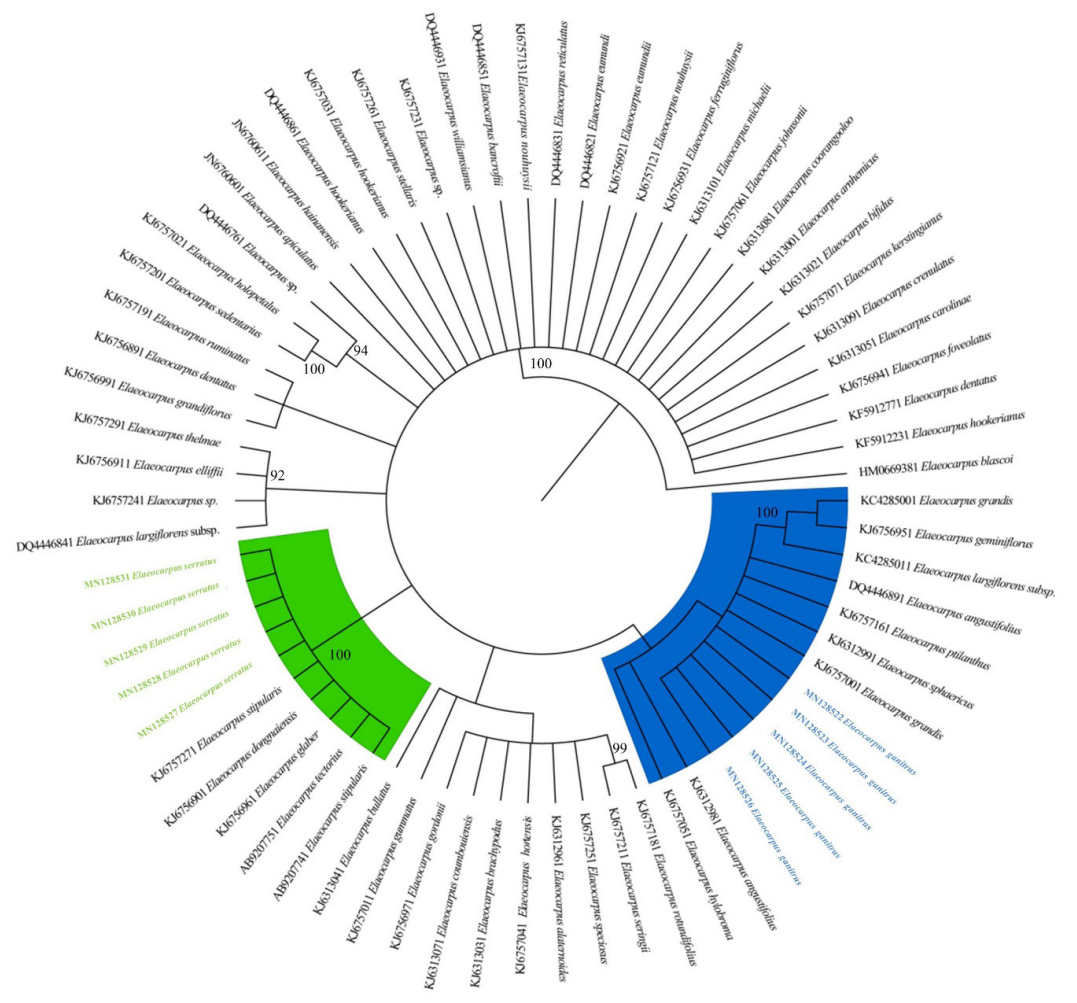

Figure 09: The rooted Bayesian tree constructed using sequences obtained for trnL-trnF (tRNA-leu gene) marker region. E. serratus (green) and $E$. ganitrus (blue) species included into two separate clades. The posterior probability values $(>80)$ are shown at the respective clades. 


\section{DISCUSSION}

E. serratus fruits are very popular in Sri Lanka.

E. serratus trees are predominantly found in wet and intermediate zones of the country; however, home garden trees are scattered all over the country. E. ganitrus trees are mainly found in wet zone and especially in districts Matale and Kandy. Therefore, in the present study we selected a set of trees of the two species from same area (Figure 2) in order to perform a comparative morphological analysis of fruits and endocarps.

The colour of E. ganitrus fruits is caused by the iridosomes present under the outer cell walls of epidermis. The iridosome reflect the blue light and that is why E. ganitrus fruits are blue in appearance (Lee, 1991). In the present study, we observed that, at complete maturity (ripe stage), fruits of different trees show a variation indicating complex genotype $\times$ environment interaction causing the blue coloration of fruits (Figure 5Ai). The large size of E. ganitrus trees and presence of apical crown of branches at great heights did not permit us to collect fruits to study the gradual development of iridosomes, colour and within plant variations. The fruits of E. serratus do not contain iridosomes and remain in lightish or olive green in skin colour (Figure 5Bi). The endocarps of E. ganitrus are culturally significant and hence economically important. We observed that endocarp size traits are not significantly affected by the environment but there is a significant within species variation observed (Table 3 and 4; Figure 4). In making wooden-bead chains for religious matters; the size, shape and the contourpattern of the endocarp surface are important. It is evident from the present analysis that the tree to tree variation of endocarp morphology (Figure 4 and 5ii), permits the selection of a specific tree for specific necklace types for particular devotees and the religious occasion or observance. The endocarps of $E$. serratus have no religious value probably because of their elongated shape causing less applicability to string as beads and the shallow contours of the endocarps make them less attractive compared to the more prominently patterned endocarps of E. ganitrus (Figure 6).

Although seasonal effect is significant for fruit size traits and the weight of endocarps, the tree- to-tree (i.e., intraspecific) variation is the highest for all the size traits (Table 3), indicating the heterogeneous nature and the presence of major effect quantitative trait loci (QTLs) causing such a high variation. It is also interesting to note that length and diameter are negatively correlated probably implying that during the cause of fruit development, certain degree $(-25 \%$ according to the present study) of length to diameter ratio is maintained retaining the identity of fruit geometry to keep the dispersal agents like birds attracted or an avenue of co-evolution with them. If there are specialized dispersal agents (Lee, 1991 reported fruit-eating pigeons, small mammals and Cassowary for E. ganitrus citing Crome, 1976; Frith et al., 1976; Stocker and Irvine, 1983; Pratt and Stiles, 1985), the genetic determination of specific endocarp-geometry is important for the survival of the species.

The organoleptic analysis revealed that the tasters prefer the blue colored appearance of the $E$. ganitrus fruits than the olive-green colored $E$. serratus fruits. However, for all the other taste parameters, E. serratus fruits were more preferred (Table 7). The blue look of E. ganitrus fruits is gorgeous and everyone prefers this uniqueness; however, the reason for high preference on the other parameters due to the fact that E. serratus is more common in Sri Lanka as a fruit. The people are so used to the 'weralu' taste, aroma, texture and sourness. Many people do not even know the existence of 'blue weralu' within the country and it is a relatively less known fruit type for the consumption which may have caused the lower preference-ratings. Those who see the $E$. ganitrus fruits for the first time in Sri Lanka, always think that they are 'toys' made from playclay. The less awareness of E. gantrus makes it a more under-utilized crop than E. serratus.

According to the sequence polymorphism obtained from the trnH-psbA and trnL-trnF (tRNA-leu gene) marker regions, it was evident that there is no intraspecific genetic variation present within the species (Figure 8). According to the clustering pattern in Bayesian tree, $E$. ganitrus and E. serratus form two separate clusters. Furthermore, within E. serratus cluster, there is no significant interspecific variation (Figure 9). There is a detectable variation within 
the E. ganitrus cluster. According to Baba, (2013), E. stipularis, E. dongnaiensis and E. glaber form the Asian clade, and according to the obtained results, E. stipularis, E. tectorius, E. dongnaiensis, E. glaber and all five E. serratus accessions form a monophyletic clade ( $\mathrm{pp}=100)$. Though E. angustifolius and E. sphaericus are generally used as synonyms for E. ganitrus; $E$. angustifolius and E. sphaericus are not completely homogenous (Baba, 2013). However, according to out results, E. grandis, E. angustifolius, E. ptilanthus, E. sphaericus, E. hylobroma, E. geminiflorus, E. largiflorens subsp. and all five E. ganitrus accessions form a separate cluster $(\mathrm{pp}=69)$. According to the phylogenetic analysis of E. ganitrus and E. serratus, the interspecific genetic variation is more prominent, and the intraspecific variation is not apparent implying that the genetic variation is independent from the selection pressures exerted by environment.

\section{CONCLUSIONS}

The morphometric analysis of fruits and endocarps of E. ganitrus and E. serratus revealed that the size traits are predominantly affected by the individual tree (i.e. intraspecific variation) than the environmental effect. Although fruit size and endocarp weight parameters are affected by the season $(p<0.05)$, the length and diameter of the endocarps are seasonal independent and tree specific. This tree specificity enables the devotees to harvest characteristic beads from specific trees to string diverse necklaces for various religious functions and devotees. Except colour, people prefer E. serratus fruits than E. ganitrus fruits. The trnH-psbA and trnL-trnF barcoding markers clearly point out the species difference among $E$. ganitrus and E. serratus. The sequence pop set available in Baba (2013) for trnL-trnF (only pop set available for Elaeocarpus spp. to date) positioned the trees of E. ganitrus assessed in the present study in the respective clade and $E$. serratus in a clade with E. stipularis, E. tectorius, E. dongnaiensis and E. glaber. Although present study set the species delimits for two studied species, worldwide attempts are needed to fully resolve the molecular phylogenetic relationships of E. ganitrus, E. serratus and other worldwide Elaeocarpus spp.

\section{ACKNOWLEDGMENTS}

Authors wish to thank site-owners of the trees for the permission to access trees and collect samples.

\section{Data Availability Statement}

The nucleotide dataset generated during and/or analysed during the current study are available in the GenBank, and https://www.ncbi.nlm.nih.gov/ nuccore (trnH-psbA: MN119517-MN119526; trnL-trnF: MN128522-MN128531).

The other datasets generated during and/or analysed during the current study are available from the corresponding author on reasonable request.

\section{REFERENCES}

Baba, Y. (2013). Evolution, systematics and taxonomy of Elaeocarpus (Elaeocarpaceae) in Australia. Retrieved from http://researchonline.jcu.edu.au/. 05. 08. 2018.

Cavanaugh, J. E. (1997). Unifying the derivations for the Akaike and corrected Akaike information criteria. Statistics and Probability Letters. 33(2): 201-208. https://doi.org/10.1016/S01677152(96)00128-9.

Coode, M. J. E. (1983). Research highlights. Kew Bulletin. 38: 347-427.

Coode, M. J. E. (2004). Flowering Plants: Dicotyledons. Springer Science and Business Media. 135144. 
Coode, M. J. E. (2010). Elaeocarpus for Flora Malesina: New taxa and understanding in the ganitrus group. Kew Bulletin. 65(5): 355-399. https://doi.org/10.1007/s12225-010-9223-2.

Christenhusz, M. J. M. and Byng, J. W. (2016). The number of known plants species in the world and its annual increase. Phytotaxa. 261(3): 201-217. http://dx.doi.org/10.11646/phytotaxa.261.3.1.

Crome, F. H. J. (1976). Some observations on the biology of the cassowary in northern Queensland. Emu. 76: 8-14.

Das, D. K. (1987). Edible fruits in Bangladesh. Forest Research Institute of Bangladesh, Chittagong.

Dassanayake, M. D. (1980). A Revised Handbook of the Flora of Ceylon. Amerind Publishing Co. Pvt. Ltd, New Delhi. 173-175.

Doyle, J. J. (1990). Isolation of plant DNA from fresh tissue. Focus. 12: 13-15.

Frith, H. J., Crome, F. H. J. and Wolfe, T. O. (1976). Emu- Austral Ornithology. 76(2): 49-58. https:// doi.org/10.1071/MU9760049.

Huelsenbeck, J. P. and Ronquist, F. (2001). MrBayes: Bayesian inference of phylogeny. Bioinformatics. 17: 754-755.

Kumar, S., Stecher, G. and Tamura, K. (2016). MEGA7: Molecular Evolutionary Genetics Analysis version 7.0 for bigger datasets. Molecular Biology and Evolution. 33(7): 1870-1874. https:// doi.org $/ 10.1093 / \mathrm{molbev} / \mathrm{msw} 054$.

Kumar, S. T., Shanmugam, S., Palvannan, T. and Kumar, V. M. B. (2008). Evaluation of Antioxidant Properties of Elaeocarpus ganitrus Roxb. Leaves. Iranian Journal of Pharmaceutical Research. 7(3): 211-215. DOI: 10.22037/IJPR.2010.767.

Lee, W. D. (1991). Ultrastructural basis and function of iridescent blue colour of fruits in Elaeocarpus. Nature. 349: 260-261. DOI10.1038/349260a0.

Miller, M. A., Pfeiffer, W. and Schwartz, T. (2010). Creating the CIPRES Science Gateway for inference of large phylogenetic trees. Gateway Computing Environments Workshop (GCE). Retrieved from http://www.ieexplore.ieee.org/abstract document/5676129. 24. 01. 2019.

Mohanan, N. and Sabu, T. (2002). Ceylon Olive: a lesser-known wild edible fruit tree. Indian Horticulture. Retrieved from http://aims.fao.org/. 15. 06. 2018.

Pant, M., Lal, A., Bisht, P. and Rani, A. (2013). Elaeocarpus sphaericus: A Tree with Curative Powers: an overview. Research Journal of Medicinal Plant. 7(1): 23-31. DOI: 10.3923/rjmp.2013.23.31.

Pratt, T. K. and Stiles, E. W. (1985). The influence of fruit size and structure on composition of frugivore assemblages in New Guinea. Biotropica. 17: 314-321.

Pushpakumara, D. K. N. G., Gunasena, H. P. M. and Singh, V. P. (2007). Underutilized Fruit Trees in Sri Lanka. World Agroforestry Centre, South Asia Regional Office, New Delhi. 434-485.

Rahman, M. M., Amin, M. N. and Ahmad, S. (2003). Rapid clonal propagation of native olive (Elaeocarpus robustus roxb.) using tissue culture technique. Journal of Biological Science. 3:1107-1113. DOI: $10.3923 /$ jbs.2003.1107.1113.

Rambaut, A. (2014). FigTree, a graphical viewer of a phylogenetic trees. Available at http://ree. bio. ed.ac. uk/software/figtree. 24. 01. 2019. 
Raven, P. H. and Axelrod, D.I. (1974). Angiosperm Biogeography and Past Continental movements. Annals of the Missouri Botanical Garden. 61(3): 539-661.

Rodriguez, F. J., Oliver, J.L., Marin, A. and Medina, J. R. (1990). The general stochastic model of nucleotide substitution. Journal of Theoretical Biology. 142(4): 485-501.

Sang, T., Crawford, D. and Stuessy, T. (1997). Chloroplast DNA phylogeny, reticulate evolution, and Biogeography of Paeonia (Paeoniaceae). American Journal of Botany. 84(8): 1120. DOI: $10.2307 / 2446155$.

Singh, A.K., Kumar, R. and Rai, D. V. (2016). Study on Engineering Properties of Rudraksha (Elaeocarpus ganitrus Robx.) for Design and Development of Agricultural Processing Unit. International Journal of Scientific and Engineering Research. 7(5): 105-118.

Singh, U. V., Ahlawat, S. P. and Bisht, N. S. (2003). Nursery Technique of Local Tree Species. State Forest Research Institute, Itangar. 10.

Stamatakis, A. (2006). RAxML-VI-HPC: maximum likelihood-based phylogenetic analyses with thousands of taxa and mixed models. Bioinformatics. 22(21): 2688-2690. https://doi. org/10.1093/bioinformatics/btl446.

Stamatakis, A., Hoover, P. and Rougemont, J. (2008). A rapid bootstrap algorithm for the RAxML web servers. Systematic Biology. 57(5): 758-771. https://doi.org/10.1080/10635150802429642.

Stocker, G.C. and Irvine, A.K. (1983). Seed dispersal by Cassowaries (Casuarius casuarius) in North Queensland's rainforests. Biotropica. 15: 170-176.

Taberlet, P., Coissac, E., Pompanon, F., Gielly, L., Miquel, C., Valentini, A., Vermat, T., Corthier, G., Brochmann, C. and Willerslev, E. (2007). Power and limitations of the chloroplast trnL (UAA) intron for plant DNA barcoding. Nucleic acids research. 35(3): e14.

Thompson, J. D., Higgins, D. G. and Gibson, T. J. (1994). CLUSTAL W: improving the sensitivity of progressive multiple sequence alignment through sequence weighting, position-specific gap penalties and weight matrix choice. Nucleic Acids Research. 22(22): 4673-4680. https://doi. org/10.1093/bioinformatics/btm404.

Zmarzty, S. (2001). Revision of Elaeocarpusm (Elaeocarpaceae) section Elaeocarpus in Southern India and Sri Lanka. Kew Bulletin. 56(7): 407-447. DOI: 10.2307/4110964. 